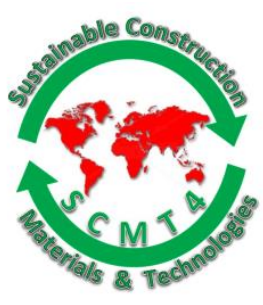

SCMT4

Las Vegas, USA, August 7-11, 2016

\title{
Experimental Investigation of Factors Influencing External Corrosion of Buried Pipes
}

\author{
Muhammad Wasim ${ }^{1 \mathrm{a}}$, Chun-Qing Li, D.J.Robert*1b, M. Mahmoodian ${ }^{1 \mathrm{c}}$, and S. Setunge ${ }^{1 \mathrm{~d}}$ \\ ${ }^{1}$ School of Civil Envir. \& Chem. Eng. RMIT University, GPO. Box 2476, Melbourne Central, Vic 3001, \\ Australia. ${ }^{1 a}$ Email: <s3442859@student.rmit.edu.au>, ${ }^{1 b}$ Email: $\langle$ chunqing.li@rmit.edu.au〉, \\ ${ }^{1 c}$ Email:<dilan.robert@rmit.edu.au>, ${ }^{1 d}$ Email: <mojtaba.mahmoodian@rmit.edu.au>, \\ ${ }^{1 e}$ Email: <sujeeva.setunge@ rmit.edu.au>.
}

\begin{abstract}
Corrosion is a serious concern for owners and managers of buried pipelines as it can cause time dependent structural degradation which adversely affects the service life of pipelines. Leaks or rupture caused by corrosion are commonly identified problems in buried metal pipelines which can lead for catastrophic failures causing significant socio-economic losses for consumers as well as water utilities. Despite the periodic inspection of these buried pipelines, the corrosion attack is still one of the major problems in almost every part of the world. Although the corrosion attack can manifest in both internal and external surfaces of pipes, the external corrosion has been reported as the root cause of failure for these pipes. Therefore, an understanding of the external corrosion mechanism and its contributing factors can bring significant insight for corrosion protection of newly installed pipes and maintaining the aged pipes. The current research presents an innovative approach to explore the effects of factors influencing external corrosion of buried metal pipes. The method showed effective outcomes for evaluating the coupled effect of soil $\mathrm{pH}$ and moisture on the external corrosion behavior of cast iron pipes buried in natural soil.
\end{abstract}

\section{INTRODUCTION}

The corrosion of existing buried ferrous metal water pipes is a matter of primary importance due to its social impacts and high cost incurrence for almost every part of the world. It has been reported that water utilities in the United States of America (USA) replace a high number of their water mains each year because of their deteriorating condition (Grigg, 2006). The most recent statistics for Australia suggest that $80 \%$ of water utilities are buried and more than $70 \%$ of these utilities are composed of ferrous metals pipes (Worthington, 2011). The main problems of these buried metal pipes are leaks and rupture which cause significant direct and indirect financial losses. The reason of such leaks in buried pipes is reported as the external corrosion by several researchers (Kleiner and Rajani, 2001, Melchers, 2013, Mahmoodian and Li 2012, and Li and Mahmoodian 2013).

There is a voluminous research literature available on external corrosion of buried pipes, yet the external corrosion of buried pipes is not preventable due to the heterogeneity of the soils despite the use of advanced corrosion protective techniques such as sacrificial anodes, coatings and impressed current (Kim and Kim, 2001, Yan et al., 2008, Sparks, 2003, Cristiani et al., 2008, Maldonado and Veleva, 1999). Such 
heterogeneity of the soils is one of the main factors which limit the acceptance and reliability of external corrosion models derived from various field investigations conducted on ferrous metal buried pipes. Several field studies have been conducted by researchers in the past to investigate the external corrosion of buried metal pipes (Denison and Hobbs, 1934, Schwerdtfeger, 1953, Romanoff, 1957, Murray and Moran, 1989, Melchers, 2013, Petersen et al., 2013). These field investigations have been found useful mainly to identify the external corrosion contributing factors in soils. These factors are soil resistivity, redox potential, $\mathrm{pH}$ and moisture content, particle size distribution, organic content, mineralogical composition and structure. However, the direct relationship between each of these factors and corresponding corrosion of buried pipes are not well established.

Moreover, several laboratory investigations have also been conducted to examine the effect of soil environment on metal pipes external corrosion. But, the scope of such studies was limited to exploring the effects of soil moisture content variations and corresponding corrosion (Gupta and Gupta 1979, Murray and Moran 1989, Wan et al., 2013, Noor and Al-Moubaraki, 2014). The reason of such limited studies on real soils could be again due to the heterogeneity of soil structure.

To overcome the heterogeneity of soil structure, considerable research work has been conducted in the past on external corrosion behavior of pipes using simulated soil solutions. The effect of $\mathrm{pH}$ on corrosion of buried metal pipes was investigated using simulated soils solutions (Liu et al., 2008, Liu et al., 2009b, Liu et al., 2009a, Wu et al., 2010). Further, several researchers investigated the effect of chloride contents on corrosion of buried pipes using simulated soil solutions (Belmokre et al., 1998, Benmoussa et al., 2006, Mohebbi and $\mathrm{Li}, 2011)$. The carbonates concentrations on corrosion of small simulated pipes coupons was also investigated in the past (Zhang and Cheng, 2010, Oskuie et al., 2012, Wang and Atrens, 2003, Fu and Cheng, 2010, Eliyan et al., 2012, Xu and Cheng, 2012), but excluding oxygen diffusion consideration. A significant focus has also been devoted by researchers on stress corrosion cracking (SCC) of buried metal pipes such as SCC of API X65 (Eslami et al., 2010, Eslami et al., 2011) and API X70 steels in near-neutral pH and/or high pH environments (Liu et al., 2008, Liu et al., 2009b, Liu et al., 2009a, Tang and Cheng, 2011, Kentish, 2007, Liu et al., 2012).

Thus, by consideration of the current state of art in the research area, it can be noted that there is a clear gap in the research related to the coupled effect of soil $\mathrm{pH}$ and moisture for corrosion of metal pipes buried in natural soils. In order to address this gap in research, a unique methodology is devised in the current research by using pipes buried in real soil environment. The soil has been prepared to achieve high degree of uniformity by uniformly compacting in layers of soil blended with acid and water for the whole depth of burial. The purpose of uniform compaction is to avoid variation in aeration by keeping constant void ratio and permeability so that the real effect of $\mathrm{pH}$, moisture and depth of burial on corresponding corrosion of pipes can be investigated accurately.

\section{EXPERIMENTAL METHODOLOGY}

An innovative external corrosion evaluation approach was developed to investigate the effect of contributing factors on external corrosion of buried cast iron pipes. The values of soil $\mathrm{pH}$, moisture and depth of burial were kept uniform in the tests. The care was taken to minimize variation in aeration by keeping the soil void ratio constant and consequently controlling the uniform density for the whole depth of burial. The experimental methodology and the test plan are discussed in detail in the following sections.

\section{Test coupons}

The test coupons used in this experimental study were made up of cast iron pipes having the same composition and wall thickness as of old exhumed cast iron pipes in Melbourne. The material composition 
of cast iron coupons are showed in table 1 . The dimensions of the cast iron coupons (polished) were selected to be $100 \mathrm{~mm} \times 20 \mathrm{~mm} \times 10 \mathrm{~mm}$ as per to ASTM $1820 \mathrm{E}$ with the intention of conducting fracture toughness tests at certain exposure times (i.e. to capture the time dependent corrosion). The effect of corrosion on fracture toughness will be presented in future research.

Table 1. Cast Iron Composition

\begin{tabular}{|l|l|l|l|l|l|l|l|l|l|l|l|}
\hline $\mathrm{C}$ & $\mathrm{Mn}$ & $\mathrm{Si}$ & $\mathrm{S}$ & $\mathrm{P}$ & $\mathrm{Ni}$ & $\mathrm{Cr}$ & $\mathrm{Mo}$ & $\mathrm{Cu}$ & $\mathrm{Ti}$ & $\mathrm{Al}$ & $\mathrm{Mg}$ \\
$\%$ & $\%$ & $\%$ & $\%$ & $\%$ & $\%$ & $\%$ & $\%$ & $\%$ & $\%$ \\
$\%$
\end{tabular}

\section{Soil description and test set up preparation}

The soil used for the experimental set up was obtained from a land fill site in Melbourne. It was characterized as fined grained silty clay. The chemical and mineral composition, resistivity and $\mathrm{pH}$ of the soil are shown in table 2. As the soil received from the field was consisted in the form of big lumps, it was crushed to uniform size by crusher and further sieved using BS 410 having aperture size of $2.36 \mathrm{~mm}$ as shown in figure 1 .

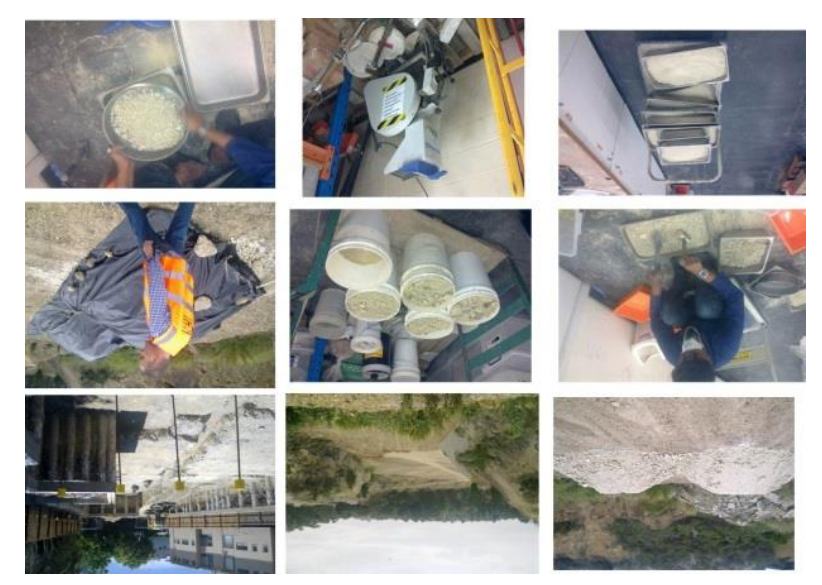

Figure 1. Soil procurement and processing for required size

Table 2. Test Soil Composition and its Properties

\begin{tabular}{|c|c|}
\hline $\begin{array}{c}\text { Soil properties and } \\
\text { Components }\end{array}$ & Results \\
\hline $\mathrm{pH}$ & 8.17 \\
\hline Resistivity $(\Omega \mathrm{m})$ & 23.46 \\
\hline Chlordie $(\mathrm{mg} / \mathrm{kg})$ & 115.6 \\
\hline Sulphate $\left(\mathrm{SO}_{4}\right)(\mathrm{mg} / \mathrm{kg})$ & 50 \\
\hline Nitrate $\left(\mathrm{NO}_{3}\right)(\mathrm{mg} / \mathrm{kg})$ & 23.05 \\
\hline Organic Matter $(\mathrm{mg} / \mathrm{kg})$ & 0.26 \\
\hline Potassium $(\mathrm{mg} / \mathrm{kg})$ & 39.1 \\
\hline Calcium $(\mathrm{mg} / \mathrm{kg})$ & 333 \\
\hline Magnesium $(\mathrm{mg} / \mathrm{kg})$ & 197 \\
\hline Sodium $(\mathrm{mg} / \mathrm{kg})$ & 119 \\
\hline
\end{tabular}


A plastic container, which was not reactive for the chemicals, was used to setup the corrosion cell for external corrosion evaluation. Firstly, a bedding layer was prepared in the container with $80 \mathrm{~mm}$ height at the target dry density. Then the coupons, which were coated on all the sides except the top surface, were placed on the bedding layer. This simulates the real corrosive environment for the external pipe wall of the buried pipes. Having placed the coupons, the test compartment was divided into three compartments to minimize the disturbance to the soil and coupons during the coupon removal for mechanical testing (figure 2). After internal separation of the container, the compartments were filled with measured amount of soil with uniform compaction to maintain homogeneity in the soil while achieving the target initial condition of the tests. The detailed initial conditions of the experiment presented in this work are showed in table 3.

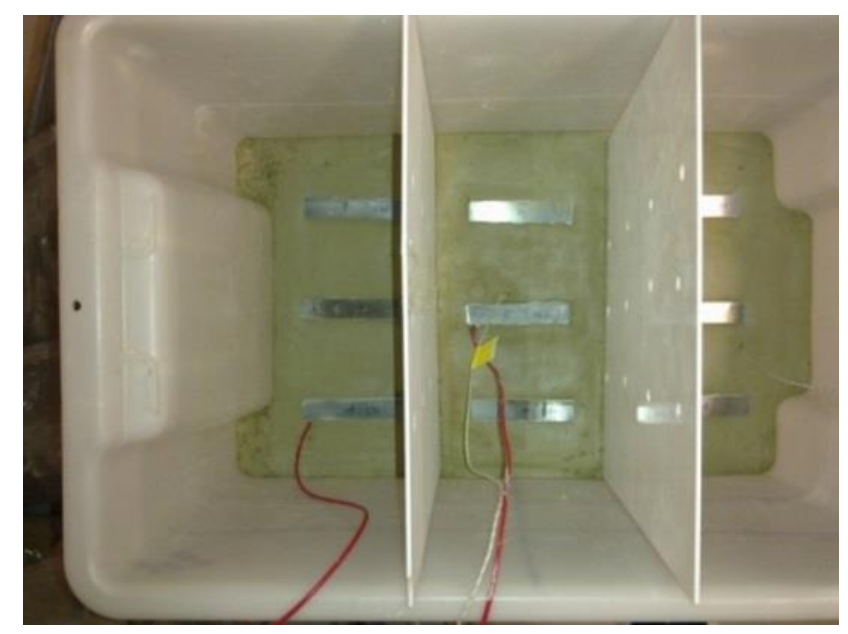

Figure 2. Coupons partitioned to avoid soil disturbance upon removal at certain age

Table 3. Initial conditions of the test

\begin{tabular}{|c|c|}
\hline Initial Test Condition & Value \\
\hline Ambient humidity & $43 \%$ \\
\hline Ambient Temperature & 19 Celsius \\
\hline Dry density of soil & $1600 \mathrm{~kg} / \mathrm{m}^{3}$ \\
\hline Soil pH & 3.0 \\
\hline Moisture content of soil (including acid)/degree of saturation & $20 \% / 80 \%$ \\
\hline
\end{tabular}

\section{INSTRUMENTATION}

\section{pH monitoring}

Diluted $\mathrm{HCl}$ was mixed with water to achieve a target $\mathrm{pH}$ of 3 . The $\mathrm{pH}$ measurements were obtained using direct soil $\mathrm{pH}$ meter as shown in figure 3 All the mixing was done in the mixer to achieve uniform mixing of the soil. After the mixing, the soil was kept in sealed plastic bags to avoid moisture loss and maintain uniform acid contamination as shown in figure 4. 

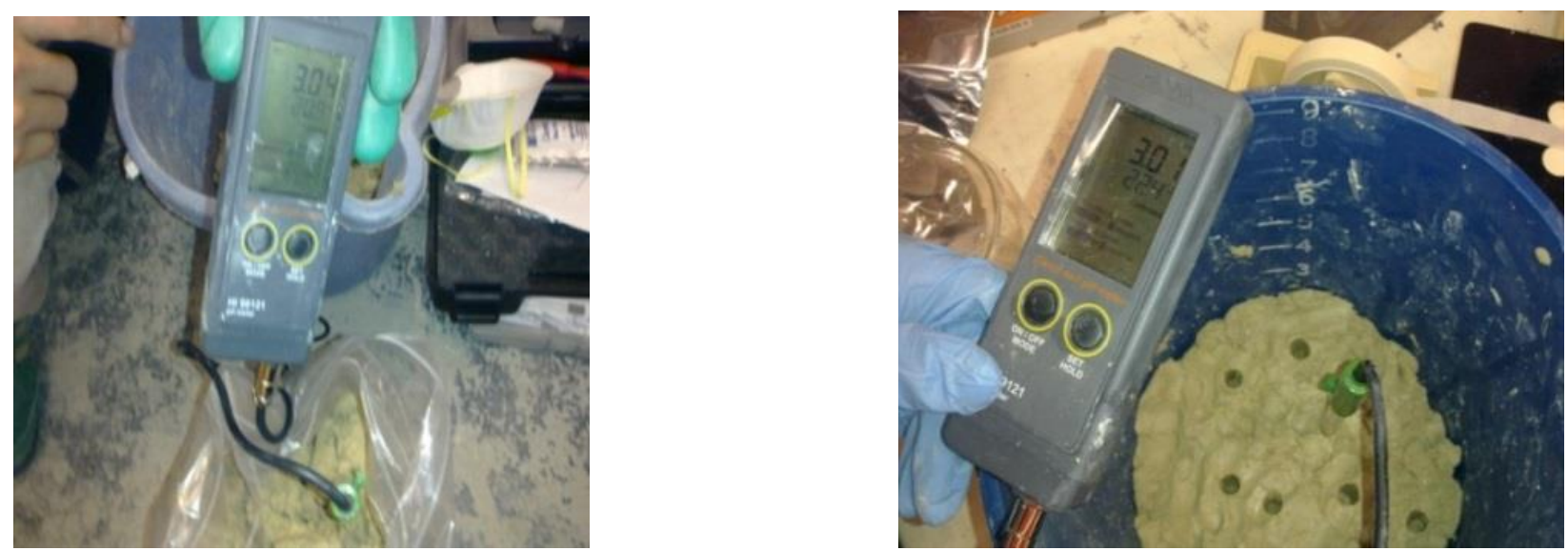

Figure 3. Soil pH measurements before putting in the bags and after 24 hours by Hanna Instrument

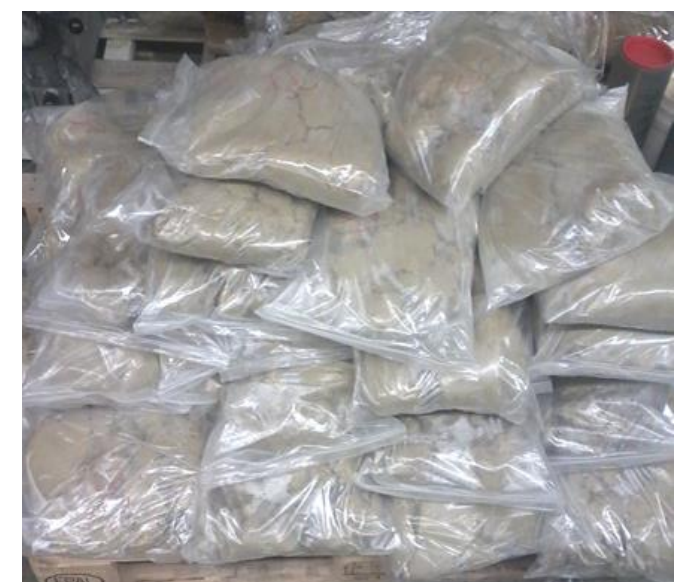

Figure 4. Soil stored in plastic bags to avoid moisture loss and uniform acid contamination for 24 hours

\section{Temperature monitoring}

Thermometers were embedded at a burial depth of $300 \mathrm{~mm}$ for investigating the temperature variation at this particular depth where specimens were buried. The ambient laboratory temperature was also observed on daily basis for the whole experimental duration.

\section{Moisture and its monitoring}

The soil moisture was kept constant at $20 \%$ which is equivalent of $80 \%$ degree of saturation at the target dry density (i.e. $1.6 \mathrm{~g} / \mathrm{cm} 3$ ). The loss of moisture was globally monitored by placing the whole setup on a scale, and water was sprayed to the soil surface frequently to compensate the loss of water due to evaporation. A soil moisture sensor was also embedded into the test set up to observe the moisture profile of the soil. The test assembly; data logger, computer and corrosion cell placed on load cell are shown in figure 5 . 


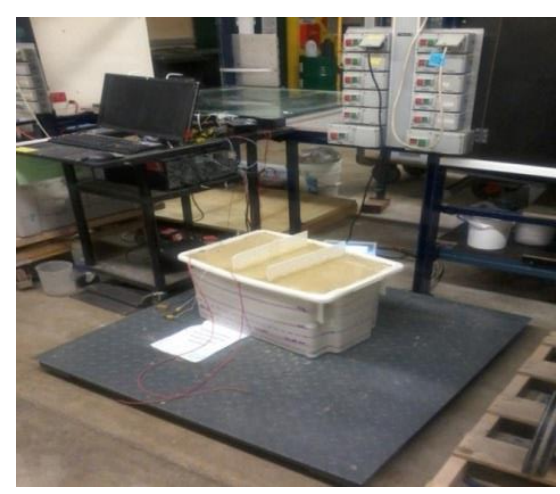

\section{Figure 5. The final assembly for the lab experimental set up including Test container, data logger and Load cell}

\section{Electrochemical Measurements for Corrosion Monitoring}

Two of the test coupons were connected with wires to get the electrochemical measurements. The electrochemical corrosion monitoring of the experimental set up was done by means of ACM Linear Polarization Resistance (LPR ) instruments. The LPR technique is the only corrosion monitoring method by which the corrosion rates are measured directly, in real time. Although, it is limited to electrolytically conducting substances, the response time and data quality of this technique make it clearly superior to all other forms of corrosion monitoring specially for external corrosion assessment of buried ferrous metal pipelines (NACE 2010). The LPR data enables a more detailed assessment of the structural condition and is a good corrosion estimation tool in deciding upon the optimum remedial strategy to be adopted. Therefore it can be said that the LPR measurements obtained are acceptable estimation for corrosion. LPR measurements in the laboratory are performed as described in ASTM G 59.

In LPR, the coupon potential is scanned between $-30 \mathrm{mV}$ saturated calomel electrode (SCE) and $+30 \mathrm{mV}$ (SCE) of the free-corrosion potential at a scan rate of $0.17 \mathrm{mV} / \mathrm{s}$ (SCE). The ensuing current is monitored as a function of potential. The tangent to the potential current plot at the free-corrosion potential is the polarization resistance (LPR value). These LPR values are then converted to corrosion currents using the Stern-Geary equation $\mathrm{Rp}=\beta /$ Icorr where Icorr is the corrosion current density in $\mathrm{A} / \mathrm{cm} 2, \beta$ is the SternGeary constant and Rp is the polarization resistance (NACE 2010).

\section{EXPERIMENTAL RESULTS AND DISCUSSION}

\section{Setup Capability - Maintain target test conditions}

From the 74 days of observations, It was noted that the moisture and soil $\mathrm{pH}$ were maintained at the target values. Water content at the soil surface as well as at $300 \mathrm{~mm}$ depth remained at the desired level (figure 6). The monitoring of $\mathrm{pH}$ indicated that it held fairly uniform for the whole test duration as shown in figure 7. The embedded thermometers showed an initial temperature variation than the ambient temperature for the first 25 days of test duration (figure 8). The possible reason for this lower temperature in the initial days may be due to the lower temperature of the tap water added to the soil at the time of mixing. The other reasons could be internal soil reactions and level of compaction which prevented the increase of temperature for 25 days. 


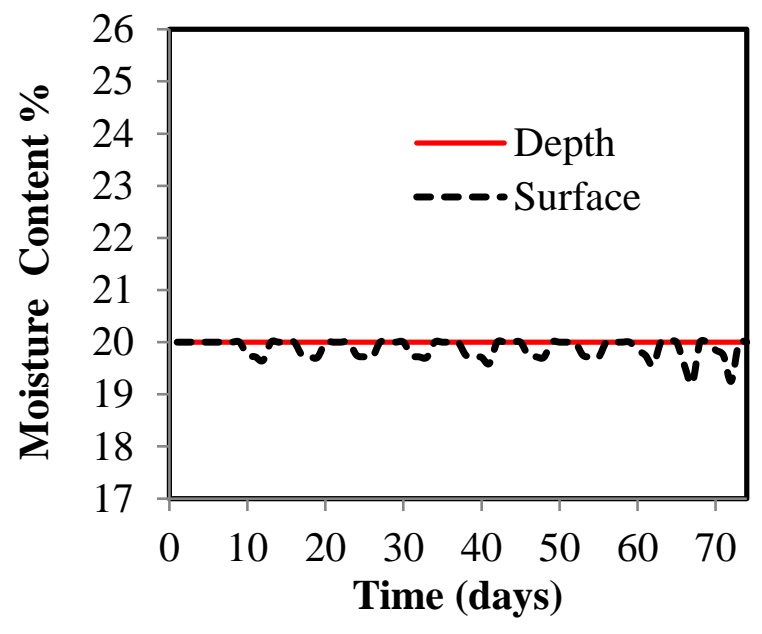

Figure 6. \% Moisture content of the soil at the depth of burial level and surface

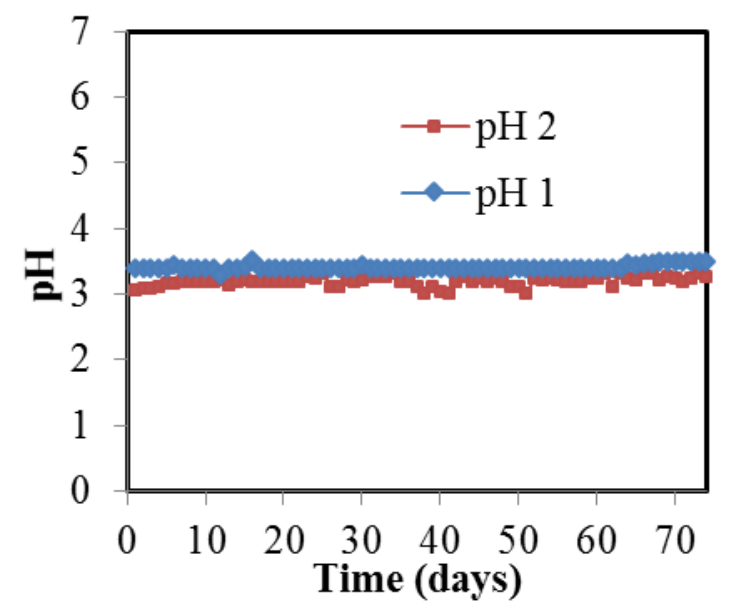

Figure 7. pH of the middle and corner portion of the corrosion cell set up

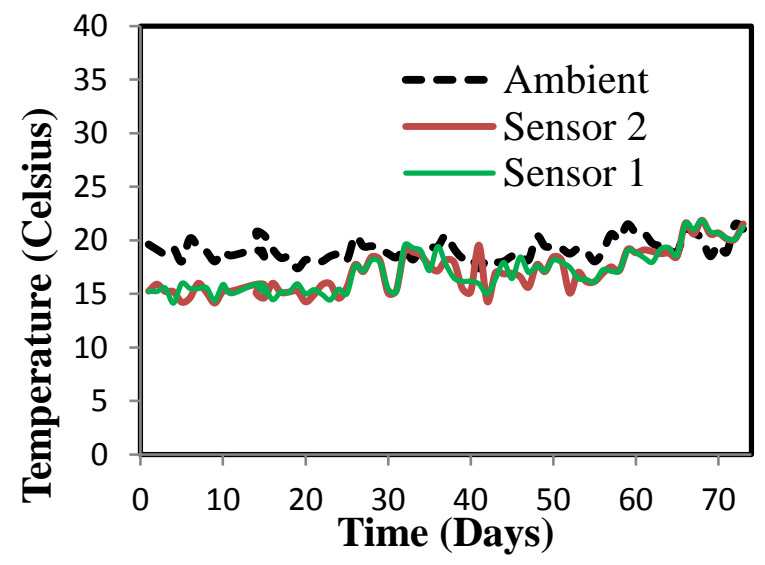

Figure 8. Temperature of the ambient and soil environments by thermometers at a burial depth of $300 \mathrm{~mm}$ burial

\section{Setup capability - Corrosion assessment}

The corrosion current measurements were recorded right after the first day of experimental set up. The Icorr reading at day 1 was $6.86 \mu \mathrm{A} / \mathrm{cm}^{2}$, which remained nearly the same for 20 days, indicates the strong passive film on the metal coupon surface preventing the further incline on the external corrosion of the buried coupons as shown in Fig 9. After 20 days of observation, the corrosion current values were started to incline and reached to the maximum peak value of $14.09 \mu \mathrm{A} / \mathrm{cm}^{2}$ on 47 th day due to the weakening of passive film on the metal surface and consequently the development of corrosion products. The corresponding corrosion rate for this Icorr value was calculated as $0.163 \mathrm{~mm} / \mathrm{yr}$. The results of the corrosion rates are shown in figure 10 . These results indicate that clay soil with $\mathrm{pH} 3$ is very corrosive for the external surface of buried pipes. The coupled effect of $\mathrm{pH} 3$ and moisture content of the soil weakened the developed passive film on the metal surface so that corrosion rates were reached to maximum peak value within 47 days of observations indicating the corrosion severity under the tested conditions. 


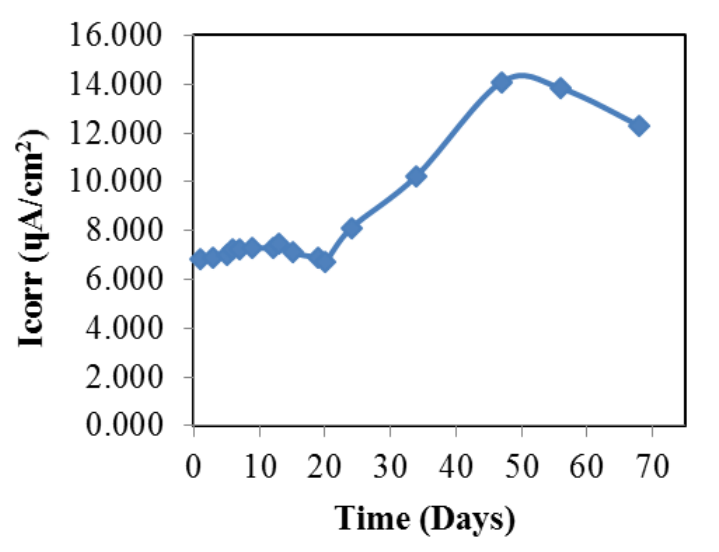

Figure 9. Corrosion current vs time

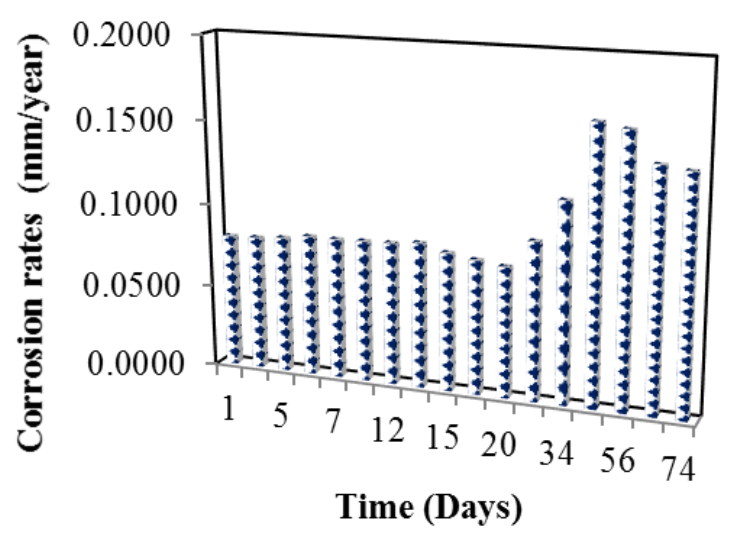

Figure 10. Corrosion rates vs time

The corrosion current after reaching peak value started to decline due to the development of corrosion products which hindered the oxygen diffusion to the metal surface resulting lower corrosion rates. It is due to this reason that after 74 days of observation, the Icorr value of $12.296 \mu \mathrm{A} / \mathrm{cm}^{2}$ was obtained. Although the corrosion rates declined after reaching the peak, the value of $12.296 \mu \mathrm{A} / \mathrm{cm}^{2}$ is still significantly high, indicating the need of repairs when such environmental condition exists near to the external surface of buried pipes

To further authenticate the experimental finding of the current research, besides corrosion current, the corrosion potential were also measured by the LPR as shown in figure 11. From the corrosion potential observation, a very high potential $-777 \mathrm{mv}$ was obtained. This value corresponds to oxygen limiting condition that accelerate the anodic reaction resulting in localized corrosion in the form of pits formation which generally result for leakages in buried pipes. These results further authenticate Icorr results and the device technique for evaluating external corrosion of buried pipes.

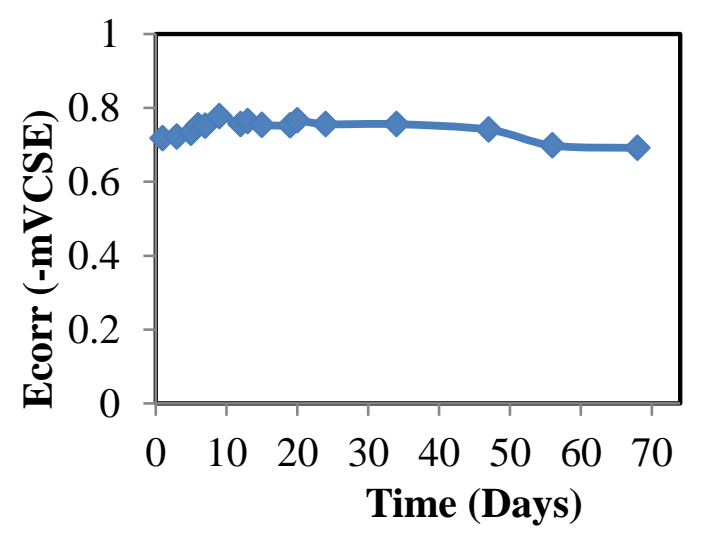

Figure 11 Corrosion potential vs time

\section{CONCLUSION}

The current research presents an innovative approach to explore the effects of factors influencing external corrosion of buried metal pipes, while highlighting the significance of low $\mathrm{pH}$ and soil moisture for severe corrosion potentials. The method showed effective outcomes for evaluating the coupled effect of soil $\mathrm{pH}$ and moisture on the external corrosion behavior of cast iron pipes buried in natural soil. A homogenous 
corrosive soil environment was created with constant void ratio, moisture, $\mathrm{pH}$ and temperature to eliminate the heterogeneity of corrosive environment which previously hindered the research investigations when soil was used as the medium of corrosion. The research is currently extending for further evaluations of metal corrosion under multiple variables, coupling with the mechanical performance of the corroded materials. It is expected that the outcomes of this research will be highly useful for the industry and buried pipes asset managers for better understanding of corrosion rates which can facilitate effective maintenance strategies.

\section{ACKNOWLEDGEMENTS}

Financial support from Australian Research Council under DP140101547 and LP150100413 is gratefully acknowledged.

\section{REFERENCES}

BELMOKRE, K., AZZOUZ, N., KERMICHE, F., WERY, M. \& PAGETTI, J. 1998. "Corrosion study of carbon steel protected by a primer, by electrochemical impedance spectroscopy (EIS) in $3 \% \mathrm{NaCl}$ medium and in a soil simulating solution." Materials and Corrosion, 49, 108-113.

BENMOUSSA, A., HADJEL, M. \& TRAISNEL, M. 2006. "Corrosion behavior of API 5L X-60 pipeline steel exposed to near-neutral $\mathrm{pH}$ soil simulating solution." Materials and Corrosion, 57, 771-777.

CRISTIANI, P., FRANZETTI, A. \& BESTETTI, G. 2008. "Monitoring of electro-active biofilm in soil." Electrochimica acta, 54, 41-46.

DENISON, I. \& HOBBS, R. 1934. "Corrosion of ferrous metals in acid soils." Journal of Research.

ELIYAN, F. F., MAHDI, E. S. \& ALFANTAZI, A. 2012. "Electrochemical evaluation of the corrosion behaviour of API-X100 pipeline steel in aerated bicarbonate solutions." Corrosion Science, 58, 181-191.

ESLAMI, A., FANG, B., KANIA, R., WORTHINGHAM, B., BEEN, J., EADIE, R. \& CHEN, W. 2010. "Stress corrosion cracking initiation under the disbonded coating of pipeline steel in near-neutral $\mathrm{pH}$ environment." Corrosion Science, 52, 3750-3756.

ESLAMI, A., KANIA, R., WORTHINGHAM, B., BOVEN, G. V., EADIE, R. \& CHEN, W. 2011. "Effect of $\mathrm{CO} 2$ and $\mathrm{R}$-ratio on near-neutral $\mathrm{pH}$ stress corrosion cracking initiation under a disbonded coating of pipeline steel." Corrosion Science, 53, 2318-2327.

FU, A. Q. \& CHENG, Y. F. 2010. "Electrochemical polarization behavior of X70 steel in thin carbonate/bicarbonate solution layers trapped under a disbonded coating and its implication on pipeline SCC." Corrosion Science, 52, 2511-2518."

GRIGG, N. S. 2006. "Condition assessment of water distribution pipes." Journal of infrastructure systems, 12, 147-153.

KENTISH, P. 2007." Stress corrosion cracking of gas pipelines - Effect of surface roughness, orientations and flattening." Corrosion Science, 49, 2521-2533.

KIM, J.-G. \& KIM, Y.-W. 2001. "Cathodic protection criteria of thermally insulated pipeline buried in soil." Corrosion Science, 43, 2011-2021.

KLEINER, Y. \& RAJANI, B. 2001. "Comprehensive review of structural deterioration of water mains: statistical models." Urban Water, 3, 131-150.

LI, C. Q., and MAHMOODIAN, M., (2013). "Risk Based Service Life Prediction of Underground Cast Iron Pipes Subjected to Corrosion", Journal of Reliability Engineering \& System Safety, Volume 119, November, Pages 102-108 
LIU, Z. Y., LI, X. G. \& CHENG, Y. F. 2012. "Mechanistic aspect of near-neutral pH stress corrosion cracking of pipelines under cathodic polarization." Corrosion Science, 55, 54-60.

LIU, Z. Y., LI, X. G., DU, C. W. \& CHENG, Y. F. 2009a. "Local additional potential model for effect of strain rate on SCC of pipeline steel in an acidic soil solution." Corrosion Science, 51, 2863-2871.

LIU, Z. Y., LI, X. G., DU, C. W., LU, L., ZHANG, Y. R. \& CHENG, Y. F. 2009b. "Effect of inclusions on initiation of stress corrosion cracks in X70 pipeline steel in an acidic soil environment." Corrosion Science, 51, 895-900.

LIU, Z. Y., LI, X. G., DU, C. W., ZHAI, G. L. \& CHENG, Y. F. 2008. "Stress corrosion cracking behavior of X70 pipe steel in an acidic soil environment." Corrosion Science, 50, 2251-2257.

MAHMOODIAN, M. and LI, C. Q. (2012). "Sensitivity analysis in structural reliability of buried pipelines", 6th International ASRANet Conference, Integrating Structural Analysis, Risk \& Reliability, 2-4 July, London, UK

MALDONADO, L. \& VELEVA, L. 1999. "Corrosivity category maps of a humid tropical atmosphere": The Yucatán Peninsula, México. Materials and Corrosion, 50, 261-266.

MELCHERS, R. E. 2013. "Long-term corrosion of cast irons and steel in marine and atmospheric environments." Corrosion Science, 68, 186-194.

MOHEBBI, H. \& LI, C. 2011. "Experimental investigation on corrosion of cast iron pipes." International Journal of Corrosion, 2011.

MURRAY, J. N. \& MORAN, P. J. 1989. "Influence of Moisture on Corrosion of Pipeline Steel in Soils Using In Situ Impedance Spectroscopy." Corrosion, 45, 34-43.

NOOR, E. A. \& AL-MOUBARAKI, A. H. 2014. "Influence of Soil Moisture Content on the Corrosion Behavior of X60 Steel in Different Soils." Arabian Journal for Science and Engineering, 1-15.

OSKUIE, A. A., SHAHRABI, T., SHAHRIARI, A. \& SAEBNOORI, E. 2012. "Electrochemical impedance spectroscopy analysis of X70 pipeline steel stress corrosion cracking in high $\mathrm{pH}$ carbonate solution." Corrosion Science, 61, 111-122.

PETERSEN, R., DAFTER, M. \& MELCHERS, R. 2013." Long-term corrosion of buried cast iron water mains: field data collection and model calibration." Water Asset Management International, 9, 13-17.

ROMANOFF, M. 1957." Underground corrosion, National Bureau of Standards Circular 579." US Government Printing Office, Washington, 25.

SCHWERDTFEGER, W. 1953. "Laboratory Measurement of the Corrosion of Ferrous Metals in Soils." National Bureau of Standards.

SPARKS, D. L. 2003. "Environmental soil chemistry." Academic press.

TANG, X. \& CHENG, Y. F. 2011. "Quantitative characterization by micro-electrochemical measurements of the synergism of hydrogen, stress and dissolution on near-neutral $\mathrm{pH}$ stress corrosion cracking of pipelines." Corrosion Science, 53, 2927-2933.

WAN, Y., DING, L., WANG, X., LI, Y., SUN, H. \& WANG, Q. 2013. "Corrosion Behaviors of Q235 Steel in Indoor Soil." Int. J. Electrochem. Sci, 8, 12531-12542.

WANG, J. Q. \& ATRENS, A. 2003. "SCC initiation for X65 pipeline steel in the high pH carbonate/bicarbonate solution." Corrosion Science, 45, 2199-2217.

WORTHINGTON, A. C. 2011. "Productivity, efficiency and technological progress in Australia's urban water utilities." Waterlines Report Series, National Water Commission, Canberra (forthcoming). 
WU, Y. H., LIU, T. M., LUO, S. X. \& SUN, C. 2010. "Corrosion characteristics of Q235 steel in simulated Yingtan soil solutions." Materialwissenschaft und Werkstofftechnik, 41, 142-146.

XU, L. Y. \& CHENG, Y. F. 2012. "Corrosion of X100 pipeline steel under plastic strain in a neutral pH bicarbonate solution." Corrosion Science, 64, 145-152.

YAN, M., WANG, J., HAN, E. \& KE, W. 2008. "Local environment under simulated disbonded coating on steel pipelines in soil solution." Corrosion Science, 50, 1331-1339.

ZHANG, G. A. \& CHENG, Y. F. 2010. "Micro-electrochemical characterization of corrosion of precracked X70 pipeline steel in a concentrated carbonate/bicarbonate solution." Corrosion Science, 52, 960-968. 